\title{
Protection against Streptozotocin-induced Diabetes by Superoxide Dismutase
}

\author{
M. J. Robbins, R. A. Sharp, A. E. Slonim, and I. M. Burr \\ Department of Pediatrics, Vanderbilt University Medical School, Nashville, Tennessee, USA
}

\begin{abstract}
Summary. Superoxide dismutase was administered intravenously to rats $50 \mathrm{~min}$ prior to intravenous administration of a diabetogenic dose of streptozotocin. A dose of $45 \mathrm{mg} / \mathrm{kg}$ streptozotocin alone produced marked glucose intolerance and a decrease in pancreatic insulin content to less than $10 \%$ of control; both of these effects were abolished by prior administration of $105 \mathrm{u} / \mathrm{g}$ of superoxide dismutase. Superoxide dismutase $(105 \mathrm{u} / \mathrm{g})$ administered $50 \mathrm{~min}$ before $65 \mathrm{mg} / \mathrm{kg}$ intravenous streptozotocin did not prevent the development of diabetes. The fall in pancreatic insulin content seen with streptozotocin alone was, however, partially reversed by superoxide dismutase.
\end{abstract}

Key words: Streptozotocin, diabetes, redox, superoxide dismutase protection.

Streptozotocin is a diabetogenic agent which causes beta cell necrosis and a permanent diabetes mellitus like syndrome $[1,2]$. Chemically, it consists of a 1 methyl-1-nitrosourea linked to the 2 carbon of $d-$ glucose. While its precise mode of action is unknown, it appears to alter the redox state of the affected cells. Specifically, streptozotocin has been shown to decrease pyridine nucleotide levels in isolated islets $[3,4]$, to decrease levels of reduced glutathione in erythrocytes [5], and to deplete erythrocytic and retinal levels of superoxide dismutase (Superoxide oxidoreductase erythrocuprin EC. 1:15.1.1 bovine) [6]. Superoxide dismutase (SOD) is a free radical scavenger which has been proposed as a major defence against the oxidizing effect of the superoxide radical [7]. This experiment was performed in order to determine if superoxide dismutase would protect against the diabetogenic effect of streptozotocin. If streptozotocin action is dependant in part on oxidation stress, with free radical production in excess of that which could be countered by normal cell mechanisms, then agents such as superoxide dismutase should provide some protection against its action.

\section{Materials and Methods}

Male Wistar rats weighing 200-250 g were used. All animals were fasted overnight prior to the administration of the pretreatment and treatment agents. Superoxide dismutase (Miles Research Laboratories) was given at a dose of $105 \mathrm{u} / \mathrm{g}$ body weight in $0.154 \mathrm{~mol} / 1$ saline. The streptozotocin, (lot 1613E, U9889: Upjohn) was the generous gift of Dr. W. Dulin and was given in citrate buffer $(0.1 \mathrm{~mol} / \mathrm{l}$, ph 4.5$)$ at a dosage of $45 \mathrm{mg} / \mathrm{kg}$ or $65 \mathrm{mg} /$ $\mathrm{kg}$. All injections were given via the tail vein under light ether anaesthesia. Rats were injected with either SOD or $0.154 \mathrm{~mol} / 1$ saline (control) fifty minutes prior to the administration of streptozotocin or saline. No rat received more than $0.4 \mathrm{ml}$ total volume for the two injections. In a separate series SOD was given at the same time as the streptozotocin. In this experiment SOD and streptozotocin were prepared separately then drawn up into a single syringe immediately prior to injection. Five days after the appropriate injection schedule, glucose tolerance tests were carried out following an overnight fast. The animals were bled by cutting the tip off the tail and then collecting the freely flowing blood. After a baseline $(0 \mathrm{~min})$ sample the animal was given an IP glucose bolus ( $1 \mathrm{~g} / \mathrm{kg}$ body wt.). Blood samples were subsequently taken at 15, 30 and $60 \mathrm{~min}$. During all bleedings the animals were maintained under light ether anaesthesia. Blood samples were analysed for glucose using a Beckman glucose analyser. The animals were sacrificed under pentobarbital sodium, $0.5 \mathrm{ml}$, anaesthesia one hour after the glucose tolerance tests. The pancreases were removed and assayed for acid ethanol extractable insulin according to the technique of Scott and Fisher [8].

\section{Results}

\section{I) Glucose Tolerance Tests}

The results of the glucose tolerance tests are presented in Figure 1. The glucose tolerance of the animals treated with SOD plus saline and those animals 
receiving SOD $50 \mathrm{~min}$ prior to streptozotocin administration did not differ significantly from the saline plus saline-treated control animals. Those animals receiving streptozotocin after a control pretreatment with saline were profoundly diabetic, with serum glucose levels significantly higher than those in

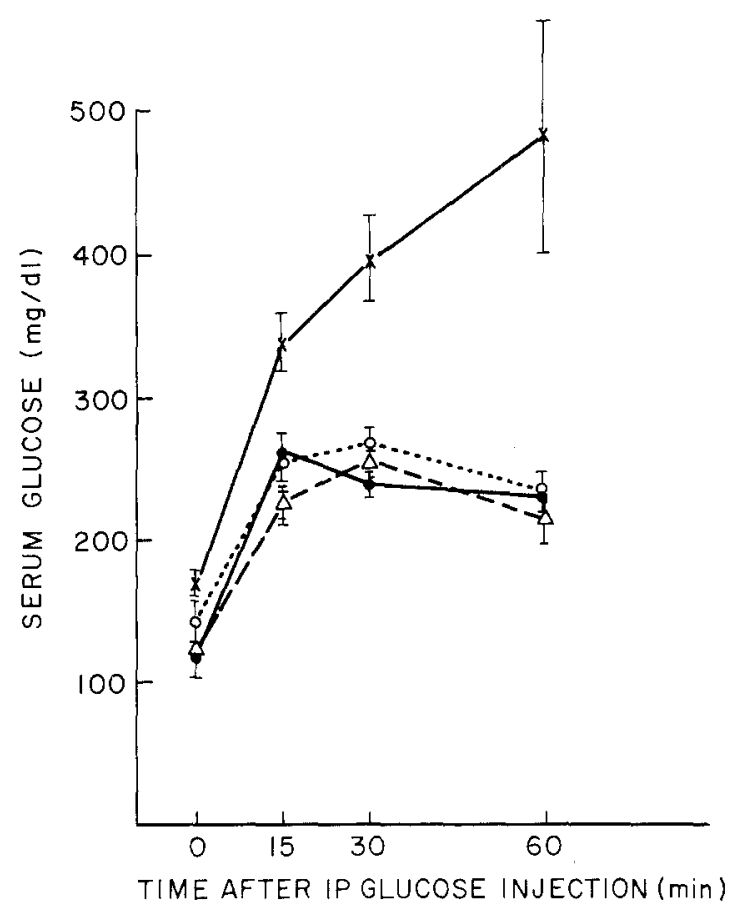

Fig. 1. Effect of superoxide dismutase (SOD) and streptozotocin on Glucose tolerance of rats. Serum glucose concentrations (vertical axis) plotted against time after intraperitoneal (IP) injection of glucose $1 \mathrm{~g} / \mathrm{kg}$ body weight. Each point represents the mean and the bars the standard errors. The unbroken line with crosses represents glucose tolerance in animals treated with streptozotocin $45 \mathrm{mg} / \mathrm{kg}$; the dotted line and open circles represents data from animals pretreated with SOD prior to streptozotocin $45 \mathrm{mg} / \mathrm{kg}$. The dashed line with triangles represents data from animals treated with SOD and no streptozotocin and the continuous line with closed circles data from animals given neither SOD or streptozotocin the saline plus saline controls $(\mathrm{p}<0.005$ at $0 \&$ 15 min: $\mathrm{p}<0.0005$ at 30 ; and $\mathrm{p}<0.025$ at $60 \mathrm{~min}$ ). In contrast those animals pretreated with SOD and $45 \mathrm{mg} / \mathrm{kg}$ streptozotocin showed consistently lower glucose values than those solely treated with streptozotocin, $45 \mathrm{mg} / \mathrm{kg}$. The confidence levels of these differences were $\mathrm{p}<0.05$ at $0 \mathrm{~min}$ and $\mathrm{p}<0.005$ at 15,30 and $60 \mathrm{~min}$. However, administration of SOD simultaneously with streptozotocin had no effect on glucose tolerance. Similarly administration of SOD prior to streptozotocin $65 \mathrm{mg} / \mathrm{kg}$ did not produce statistically significant protection as reflected by glucose tolerance.

\section{II) Extractable Insulin}

It is evident that administration of both $45 \mathrm{mg} / \mathrm{kg}$ and $65 \mathrm{mg} / \mathrm{kg}$ streptozotocin markedly reduced islet insulin content (to $<10 \%$ of control) whereas administration of SOD alone has no effect (Table 1). Administration of SOD prior to $45 \mathrm{mg} / \mathrm{kg}$ streptozotocin prevented the streptozotocin-induced fall in islet insulin content. Streptozotocin $65 \mathrm{mg} / \mathrm{kg}$ markedly reduced islet insulin content to less than $1 \%$ of control values, this effect was partially reversed by prior injection of SOD $(p<0.0005)$, Table 1. Insulin content of pancreases of rats treated with simultaneous injection of streptozotocin and superoxide dismutase did not differ from those treated with streptozotocin alone.

\section{Discussion}

Pretreatment of rats with $105 \mathrm{u} / \mathrm{g}$ - animal-weight superoxide dismutase IV $50 \mathrm{~min}$ prior to administration of $45 \mathrm{mg} / \mathrm{kg}$ streptozotocin attenuated the diabetogenic effect of streptozotocin. This effect did not appear to be secondary to direct inactivation of streptozotocin by SOD, as injection of a mixture of

Table 1. Effect of superoxide dismutase on the pancreatic insulin content of rats injected with streptozotocin

\begin{tabular}{|c|c|c|c|c|c|}
\hline \multirow[t]{2}{*}{ Exp. } & \multicolumn{2}{|c|}{ Injections } & \multirow{2}{*}{$\begin{array}{l}\text { Pancreatic insulin content } \\
\mu v / g(\chi \pm S E M)\end{array}$} & \multirow[t]{2}{*}{$n$} & \multirow[t]{2}{*}{ Significance } \\
\hline & First & Second & & & \\
\hline 1. & Saline & Saline & $495,195 \pm 61,325$ & 6 & \\
\hline 2. & Saline & Streptozotocin $45 \mathrm{mg} / \mathrm{kg}$ & $47,584 \pm 8,909$ & 6 & $v 1<0.005$ \\
\hline 3. & $\mathrm{SOD}$ & Saline & $530,822 \pm 31,569$ & 6 & $v 1 \mathrm{n} . \mathrm{s}$. \\
\hline 4. & SOD & Streptozotocin $45 \mathrm{mg} / \mathrm{kg}$ & $486,426 \pm 43,825$ & 6 & v1. n. s. \\
\hline 5. & Saline & Streptozotocin $65 \mathrm{mg} / \mathrm{kg}$ & $13,500 \pm 1,099$ & 5 & $v 1<0.0005$ \\
\hline 6. & SOD & Streptozotocin $65 \mathrm{mg} / \mathrm{kg}$ & $37,497 \pm 3,180$ & 6 & $v 5<0.005$ \\
\hline $7 .^{\mathrm{a}}$ & SOD & Streptozotocin $45 \mathrm{mg} / \mathrm{kg}$ & $50,369 \pm 5,760$ & 6 & v2 n.s. \\
\hline
\end{tabular}

All agents were given intravenously. In all experiments the first injection preceded the second injection by 50 min with the exception of experiment 7. SOD refers to $105 \mathrm{u} / \mathrm{g}$ superoxide dismutase. ${ }^{\mathrm{a}}$ In this experiment SOD was administered immediately prior to the streptozotocin 
the two agents did not provide protection. The effectiveness of SOD in this study contrasted with the previously reported ineffectiveness of a single dose in ameliorating diabetes induced by multiple doses of streptozotocin [9]. The different results may be explained by the known pharmacokinetics of the two drugs. Streptozotocin probably produces irreversable B cell damage between $10 \& 30 \mathrm{~min}$ after $\mathrm{TV}$ administration as nicotinamide administered before or up to $10 \mathrm{~min}$ after streptozotocin injection [12] can prevent streptozotocin-induced diabetes but nicotinamide given $30 \mathrm{~min}$ after streptozotocin injection cannot. SOD given IV reaches a maximum concentration in marrow stem cells at about one hour, being present in such cells from $30 \mathrm{~min}$ to $30 \mathrm{~h} \mathrm{[13].}$ Thus, in contrast with the previous report the experimental design used in this study is such that maximum intracellular SOD concentrations could be anticipated at the time of action of the streptozotocin.

The fact that SOD, a free radical scavenger, can provide some amelioration of the diabetogenic effects of streptozotocin raises the possibility that the diabetogenic effect of streptozotocin may be mediated in part by streptozotocin-induced impairment of the ability of the B cell to withstand oxidant stress. The mechanism through which streptozotocin may mediate this effect on cell redox metabolism is unknown. However, such streptozotocin-induced redox impairment could result from: First, an increase in the production of intracellular free radicals, either endogenous or exogenous (e.g. streptozotocin itself), or second from a streptozotocininduced decrease in the ability of the cell to maintain antioxidant mechanisms (e.g. inability to maintain reduced glutathione concentrations or a reduction in superoxide dismutase levels). In favour of the former possibility are the observations that nicotinamide can protect against the diabetogenic and haemolytic effects of streptozotocin $[10-12,14]$ and that streptozotocin reduces red cell [5] and islet (unpublished) GSH concentration. In favour of the latter is the observed effect of streptozotocin in decreasing superoxide dismutase activity [6]. Thus, while it is evident that the precise mechanism through which streptozotocin may influence redox metabolism in B cells is not clear there is a body of data supporting such a general role [15].

Investigation of the antitumour effects of streptozotocin have led to alternative hypotheses regarding its mode of action. For example, it has been demonstrated that streptozotocin can produce DNA damage [16] and suggested that repair of same by poly (ADP-ribose) polymerase, which utilises NAD [17] results in the observed reduction of cellular
NAD [3-5] and that the protective effect of nicotinamide could be exerted by preventing this fall in NAD. Such a mechanism could explain the ability of nicotinamide to protect against a fall in reduced glutathione in that reduced nicotine adenine dinucleotide is required for reduced glutathione production. Further, the fall in reduced glutathione could result in a greater production of free radicals and greater reliance on free radical scavengers such as superoxide dismutase. While the above hypotheses are both attractive it is necessary to recall that not only are there species differences in the susceptibility to the effect of streptozotocin but that there may also be differences between tissues with respect to the mechanism of action. For example; the effect of streptozotocin on guanylate cyclase differs from cell type to cell type [18] and the antitumour and diabetogenic actions of streptozotocin can be dissociated [10]. These facts indicate the need for caution in extrapolating from one system to another.

Acknowledgements. This study was supported in part by NIM RMS Grant \#2RO1 AM 15269. M. Robbins was a summer Fellow of the Vanderbilt University Diabetes Center visiting from Cornell University Medical School.

Thanks go to Melanie Surber and Bonnie Hite for technical and secretarial assistance respectively.

\section{References}

1. Junod A, Lambert AE, Orci L, Pictet R, Gonet AE, Renold AE (1967) Studies of diabetogenic action of streptozotocin. Proc Soc Exp Biol Med 126: 201-205

2. Rerup CC (1970) Drugs producing diabetes through damage of the insulin secreting cells. Pharmacol Rev 22: 485-518

3. Ho CK, Hashim SA (1972) Pyridine nucleotide depletion in pancreatic islets associated with streptozotocin-induced diabetes. Diabetes 21, 789-793

4. Schein PS, Cooney DA, McMenamin MG, Anderson T (1973) Streptozotocin diabetes: Further studies on the mechanism of depression of nicotinamide adenine dinucleotide concentrations in mouse pancreatic islets and liver. Biochem Pharmacol 22: 2625-2631

5. Slonim AE, Fletcher T, Burke T, Burr IM (1976) Effect of streptozotocin on red blood cell reduced glutathione: Modification by glucose, nicotinamide, and epinephrine. Diabetes 25: $216-222$

6. Crouch R, Kimsey G, Priest DG, Sarda A, Buse MG (1978) Effect of streptozotocin on erythrocyte and retinal superoxide dismutase. Diabetologia 15: 53-57

7. McCord JM, Keele BB, Fridovich I (1971) An enzyme based theory of obligate anaerobiosis: The physiological function of superoxide dismutase. Proc Natl Acad Sci USA 68: 1024-27

8. Scott DA, Fisher MM (1933) The insulin and zinc content of normal and diabetic pancreas. J Clin Invest 17: 125

9. Grodsky GM, Manning M, Rubin R (1978) Effect of superoxide dismutase (SOD) and alcohol on multiple- and single-dose streptozotocin (Sz) induced diabetes. Diabetes 27: 460

10. Schein PS, Cooney DA (1967) The use of nicotinamide to modify the toxicity of streptozotocin diabetes without loss of antitumour activity. Cancer Res 27: 2324-2332 
11. Dulin WE, Wyse BM (1969) Studies on the ability of compounds to block the diabetogenic activity of streptozotocin. Diabetes 18: 459-466

12. Stauffacher W, Burr IM, Gutzeit A, Beaven D, Veleminsky J, Renold AE (1970) Streptozotocin diabetes: Time course of irreversible B-cell damage; Further observations on prevention by nicotinamide. Proc Soc Exp Biol Med 133: 194-200

13. Petkau A, Kelly K, Chelack WS, Pleskach SD, Barefoot C, Meeker BE (1975) Radioprotection of bone marrow stem cells by superoxide dismutase. Biochem Biophys Res Commun 67: 1167-1174

14. Cuthbert S, Sharp R, Rogers M, Felts P, Burr IM (1974) Diazoxide Modification of Streptozotocin-induced diabetes in rats. Diabetes 23: 282-286

15. Slonim AE, Sharp R, Page D, Burr IM (1977) Vitamin E protection against streptozotocin induced diabetes. Diabetes 26 (Suppl 1): 417

16. Bhuyan BK, Peterson AR, Heidelberger C (1976) Cytotoxicity, mutation and DNA damage produced in Chinese hamster cells treated with streptozotocin analogs and N-methyl-N'nitro-N-nitrosoguanide. Chem Biol Interact 13: 173
17. Smulson, ME, Schein P, Mullins DW, Sudhakari S (1977) A putative role for nicotinamide adenine dinucleotide promoted nuclear protein modification in the antitumour activity of $\mathrm{N}$ methyl-N-nitrosourea. Cancer Res 37: 3006-12

18. Vesely DL, Rovere LE, Levey GS (1977) Activation of guanylate cyclase by streptozotocin and 1-Methyl-1-nitrosourea. Cancer Res 37: 28-31

19. Wik MM, Rossini, A, Glynn D (1977) Reduction of streptozotocin toxicity by 3-0-methyl glucose with enhancement of antitumour activity in murine L1210 leukemia. Cancer Res 37: 3901

Received: October 17, 1978, and in revised form: June 12, 1979

Dr. I. M. Burr

Department of Pediatrics

Vanderbilt University Medical School

Nashville, TN 37232

USA 